\title{
KEGIATAN MENUMBUHKAN JIWA KEPEMIMPINAN PADA ANAK MELALUI EDUKASI DIGITAL DI YAYASAN DOMYADHU LEBAK BULUS
}

\author{
${ }^{1)}$ Adi Hermawan, ${ }^{2)}$ Dedi Saputra, ${ }^{3)}$ Dian Nur fadhilah, ${ }^{4)}$ Eva Sulistia Pratiwi, ${ }^{5}$ Ina \\ Rakhma, ${ }^{6}$ Indah Herlina Farid, ${ }^{7}$ Lusiana, dan ${ }^{8}$ Yulia Kristiana \\ Mahasiswa Prodi D-III Sekretari Universitas Pamulang \\ adihermawan2104@gmail.com, Dedys9577@gmail.com, dianfdhlh01@gmail.com, \\ manoreva25@gmail.com,inahansami1@gmail.com,indahherlinaf@gmail.com, \\ lusiana.cute82@gmail.com, dan yulia2907@gmail.com
}

\begin{abstract}
The purpose of implementing this PKM is to provide knowledge to children so that they can be more motivated to be more creative and independent in growing their leadership spirit through digital education. Discipline itself when it raises an independent and creative attitude in which children will be able to overcome various kinds of problems faced so as to grow the spirit of leadership itself.The method used in this PKM is the presentation method which aims to make the understanding of the growth of leadership spirit easily accepted by the children. And as a result of this PKM, we hope that the children can understand more about the definition of leadership and see examples of people around them who can be used as leaders so that they better understand what a leader is like so that they know that leadership is very important and can be started in activities. daily.
\end{abstract}

Keywords: Leadership, Children, and Digital Education

\begin{abstract}
ABSTRAK
Tujuan dilaksanakannya PKM ini untuk memberikan pengetahuan kepada anak-anak agar mereka bias lebih termotivasi untuk lebih disiplin kreatif dan mandiri dalam menumbuhkan jiwa kepemimpinan melalui edukasi digital. Sikap disiplin sendiri kapan memunculkan sikap mandiri dan kreatif dimana anak-anak akan mampu mengatasi berbagai macam masalah yang dihadapi sehingga menumbuhkan jiwa kepemimpinan itu sendiri. Metode yang dipakai dalam PKM ini adalah metode presentasi dimana bertujuan agar pemahaman tentang penumbuhan jiwa kepemimpinan ini mudah diterima oleh anak-anak. Dan hasil dari PKM ini kami berharap anak-anak dapat lebih paham mengenai definisi kepemimpinan dan melihatcontoh orang sekitar yang bias dijadikan sosok pemimpin supaya mereka lebih mengerti seperti apa sosok pemimpin itu sendiri sehingga mereka tahu bahwa jiwa kepemimpinan sangat penting diterapkan dan bisa dimulai pada kegiatan seharihari.
\end{abstract}

Kata Kunci: Kepemimpinan, Anak, dan Edukasi Digital 


\section{PENDAHULUAN}

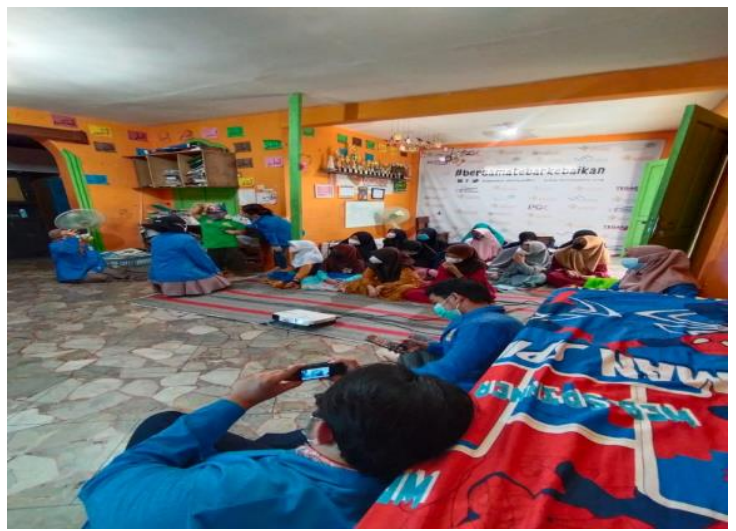

Kepemimpinan adalah perpaduan

berbagai perilaku yang dimiliki seseorang sehingga orang tersebut mempunyai kemampuan untuk mendorong orang lain bersedia dan dapat menyelesaikan tugastugas tertentu yang dipercayakan kepadanya. Kemampuan memimpin selalu merupakan pintu terhadap keefektifan pribadi maupun organisasional. Kepemimpinan merupakan bagian dari proses pengembangan diri dan kepemimpinan tidak hanya dilakukan oleh orang dewasa tetapi bisa kita asah sejak usia dini. Salah satu cara supaya kepemimpinan menjadi lebih efektif maka yang dapat dilakukan adalah:

1. Memotivasi diri untuk bekerja

2. Banyak belajar dan membaca buku

3. Memiliki kepekaan tinggi terhadap permasalahan organisasi dan komitmen tinggi untuk memecahkan masalah

4. Selalu merasa tertantang untuk mengatasi hambatan dan penghalang untuk tercapainya tujuan

\section{Mendisiplinkan diri}

Kepemimpinan yang baik adalah memiliki sifat yang disiplin. Disiplin merupakan perasaan taat dan patuh terhadap nilai-nilai yang di percaya dan tanggungjawabnya. Disiplin diri merujuk pada pelatihan yang didapatkan seseorang untuk memenuhi tugas tertentu atau untuk mengadopsi pola perilaku tertentu, walaupun orang tersebut lebih senang melakukan hal yang lain. Memberi edukasi tentang kepemimpinan dan kedisiplinan sejak dini akan menjadikan kita pribadi yang jauh lebih baik lagi ketika dewasa nanti. Jiwa kepemimpinan dalam melatih kedisiplinan pada era sekarang ini, jika dikaitkan dengan pandemi covid-19 ini masih perlu ditingkatkan khususnya bagi anak-anak. Kasus pertama Covid-19 diketahui berasal dari pasar basah Wuhan, China pada Desember 2019 yang diduga berpindah dari hewan liar ke manusia. Covid-19 (Coronavirus Disease 2019) adalah penyakit menular yang disebabkan oleh corona virus jenis baru, yakni SarsCoV-2. Covid-19 ini dapat menimbulkan gejala gangguan pernapasan akut yang ditandai dengan adanya gejala demam diatas $38^{\circ} \mathrm{C}$, batuk dan sesak nafas. Selain itu, dapat disertai dengan tubuh yang terasa lemas, nyeri otot, dan diare. Dari latar belakang masalah tersebut di atas, maka judul dalam Program Kreativitas 
Mahasiswa (PKM) adalah "Menumbuhkan Jiwa Kepemimpinan pada Anak melalui Edukasi Digital di Yayasan Domyadhu Lebak Bulus." Tujuannya untuk melatih agar anak-anak mengetahui arti kemimpinan dan diharapakan kedepannya mampu menjadi pemimpin yang baik sebagai generasi yang akan datang.

Dalam pelaksanaan kegiatan PKM yang dilakukan oleh kelompok kami tentunya besar manfaat yang dirasakan oleh anak-anak Yayasan Domyadhu Lebak Bulus, diantara manfaatnya yaitu lebih paham akan definisi kepemimpinan dan menjadikan mereka lebih termotivasi untuk menjadi generasi yang lebih baik.

\section{METODE PELAKSANAAN}

Pada tahap ini diberikan penjelasan mengenai materi tentang "Menumbuhkan Jiwa Kepemimpinan pada Anak melalui Edukasi Digital di Yayasan Domtadhu Daerah Lebak Bulus" agar mereka lebih tertarik untuk mengembangkan jiwa kepemimpinan pada diri mereka, serta menjelaskan dengan detail pentingnya mengembangkan jiwa kepemimpinan pada anak usia dini sehingga mereka tertarik dan mulai mengasah jiwa kepemimpinan dengan memulai mencari sosok pemimpin yang dikagumi. Setelah memberikan penjelasan materi maka dilakukan sesi tanya-jawab agar anak-anak mendapat kesempatan untuk menggali materi dalam dan memahami materi yang diberikan.

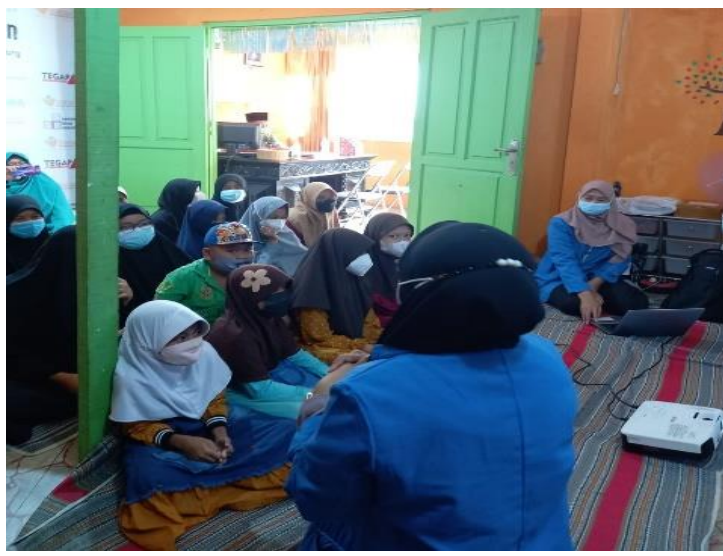

Berikut adalah tahapan-tahapan yang dilakukan oleh kelompok pelaksana Pekan Kreativitas Mahasiswa (PKM):

\section{TahapPersiapan}

a. Pada tahapan ini pelaksana memulai dengan melakukan koordinasi dengan instansi terkait.

b. Penentuan Lokasi. Pada tahap ini dilakukan kunjungan ke lokasi untuk menentukan tempat (lokasi). Dalam memilih lokasi, kami mempertimbangkan dengan jarak yang kami tempuh dari rumah anggota PKM ke lokasi PKM mengingat kondisi sedang pandemi.

\section{Perancangan Kegiatan}

Adapun tahapan yang dilakukan dalam perancangan kegiatan secara berurutan adalah sebagai berikut:
a. Pembukaan oleh MCIndah Herlina Farid 
b. Sambutan Ketua Kelompok Ina Rakhma

c. Sambutan Wakil Ketua Asrama Bapak Ridwan

d. Pembahasan materi dengan Tema Menumbuhkan Jiwa Kepemimpinan pada Anak Melalui Edukasi Digital di Yayasan Domyadhu Lebak Bulus

e. Sesi Tanya Jawab perihal materi yang di sampaikan

f. Penyerahan Cindramata dan tanda terimakasih kepada wakil ketua asrama yayasan

g. Penyerahan tanda teriamkasih kepada peserta

Adapun pendekatan yang digunakan dalam kegiatan Program Kreativitas Mahasiswa (PKM) ini adalah sebagai berikut:
a. Persentasi
b. Tanya Jawab
c. Diskusi/sharing
d. Games

Adapun peralatan yang digunakan dalam kegiatan Program Kreativitas Mahasiswa (PKM) ini adalah:
a. Proyektor
b. Laptop
c. Layar

\section{Tahap Pelaksanaan Kegiataan}

Pada tahap ini diberikan penjelasan mengenai materi tentang Menumbuhkan Jiwa Kepemimpinan pada Anak melalui Edukasi Digital di Yayasan Domyadhu Daerah Lebak Bulus agar mereka lebih tertarik untuk mengembangkan jiwa kepemimpinan pada diri mereka, serta menjelaskan dengan detail pentingnya mengembangkan jiwa kepemimpinan pada anak usia dini sehingga mereka tertarik dan mulai mengasah jiwa kepemimpinan dengan memulai mencari sosok pemimpin yang dikagumi. Setelah memberikan penjelasan materi maka dilakukan sesi tanya-jawab agar anak-anak mendapat kesempatan untuk menggali materi dalam dan memahami materi yang diberikan.

\section{PEMBAHASAN DAN HASIL}

1. Kegiatan Sosialisasi Menumbuhkan Jiwa Kepemimpinan pada Anak Melalui Edukasi Digital di Yayasan

\section{Domyadhu Lebak Bulus}

Pada tanggal 24 Juli 2021,Kami

Mahasiswa Universitas Pamulang dari Prodi D3-Sekrertari telah melaksanan PKM dengan Tema Program Sosialisasi Menumbuhkan Jiwa Kepemimpinan pada Anak Melalui Edukasi Digital di Yayasan Domyadhu 
Lebak Bulus, program ini berlangsung selama 1 hari.

Jumlah Mahasiswa yang mengadakan Program PKM terdiri dari 7 orang dan diketuai oleh Ina Rakhma, para peserta terdiri dari 15 orang anak berusia 5 tahun s.d. 12 tahun serta perwakilan Yayasan yang turut hadir mengikuti sosialisai program PKM. Dalam Kegiatan PKM ini kami memberitahukan agenda acara kepada peserta diantaranya: Pembukaan, sambutan, pemaparan materi, sesi tanya jawab, ice breaking dan pemberian hadiah sekaligus menutup acara tersebut.

Pada saat itu acara dibuka oleh Indah Herlina F selaku MC, kemudian penyampaian kata sambutan dari Perwakilan Yayasan dan Ketua Panitia lalu di lanjutkan dengan penyampaian materi.Salah satu peserta yang bernama Zahra berani memberikan berpendapat tentang siapa yang menjadi idolanya sebagai sosok pemimpin, yaittu adalah ayahnya. Terkadang dalam kita belajar memang lebih muda dari lingkungan sekitar yang kita jumpai setiap harinya. Dan menjadi pemimpin yang baik tidak hanya mereka yang membrikan teori dan sebagainya tetapi juga yang bias mencontohkan.

Para peserta juga aktif menjawab pertanyaan panitia mengenai materi yang telah di sampaikan. Dalam sesi Tanya jawab peserta cukup antusias karena mendapat hadiah dari pemateri, anakanak maju untuk menceritakan bagaimana jika ia menjadi pemimpin kelas dan pemimpin seperti apa yang diharapkan. Setelah sesi Tanya jawab selesai semua peserta mendapat bingkisan yang kurang lebih didalamnya adalah susu, kue, dan ada hand sanitizer sebagai bentuk kepedulian betapa pentingnya kebersihan di masa pandemic ini.

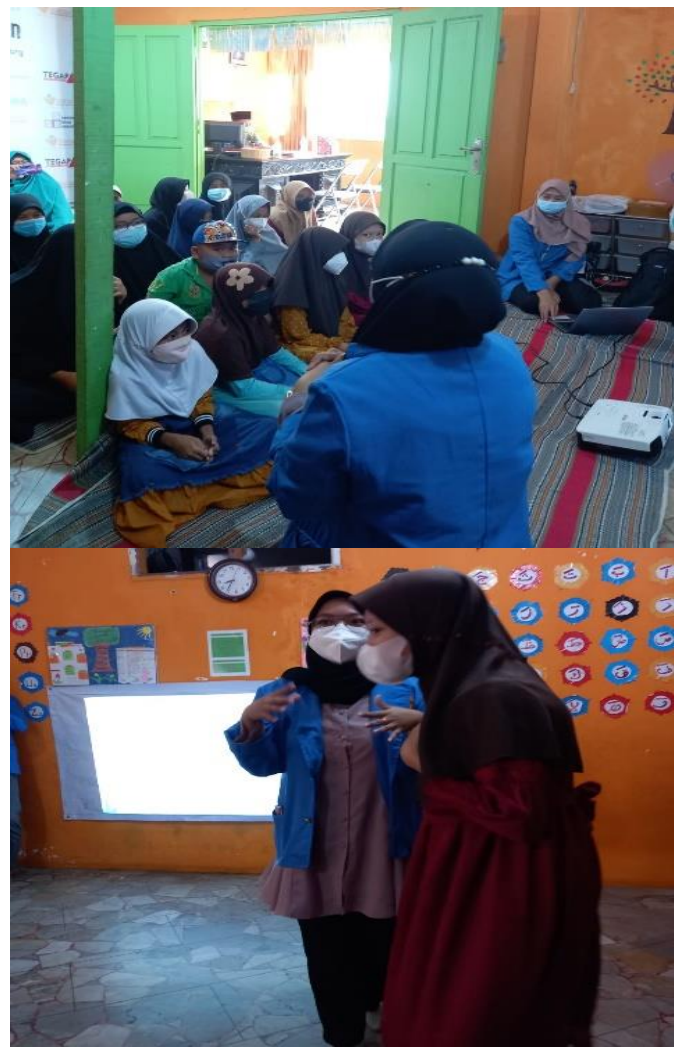

Gambar 4.1 Contoh Kegiatan Program Kreativitas Mahasiswa

2. Kendala Kegiatan Sosialisasi Menumbuhkan Jiwa

Kepemimpinan pada Anak Melalui 
Edukasi Digital di Yayasan Domyadhu Lebak Bulus

Dalam kegiatan sosialisai PKM yang berlangsung pada 24 Juli 2021 kendala pertama yang di hadapi adalah kesalahan terkait dengan jam mulai acara yang ternyata miskom dengan pengurus asrama, kami katakan mulai pukul 08.00 dan selesai pukul 09.00 karena adanya peraturan PPKM yang diperpanjang oleh pemerintah, tetapi pihak asrama menyangka acara dimulai pukul 09.00 sehingga ketika kami dating anak-anak belum siap. Sehingga waktu mulai acara mundur menjadi 08.30 dan selesai sekitar pukul 10.00 .

Kendala kedua yang kami hadapi adalah siswa/i yang pemalu sehingga kurang aktif dalam proses kegiatan PKM. Tidak semua, tetapi ada. Sehingga kami berusaha untuk mengajak terutama dalam sesi Tanya jawab agar aktif menjawab. Awalanya teman yang berani terlebih dahulu, dan teman yang pemalu maju didampingi dengan teman lainnya. Ini kami terapkan sebagai salah satu wujud pelatihan kepemimpinan yaitu harus berani tampil.

Kendala terakhir yang kami
hadapi adalah keterbatasan waktu
dikarenakan kegiatan PKM ini
dilaksanakan pada saat masa pandemi.

\section{KESIMPULAN DAN SARAN}

Berdasarkan hasil pelaporan dan pembahasan yang telah diuraikan oleh penulis, maka dapat diambil kesimpulan yaitu:

1. Kepemimpinan dapat disimpulkan dengan satu kata yaitu Influence artinya mempengaruhi, memotivasi, dan mengarahkan orang lain untuk mencapai tujuan organisasi

2. Materi yang kami berikan tentang menumbuhkan jiwa kepemimpinan pada anak Melalui edukasi digital diharapkan mampu menambah pengetahuan dan juga sebagai landasan yang kokoh untuk mewujudkan mimpi serta tujuan hidupnya. Jiwa kepemimpinan pada anak melatih rasa tanggung jawab, disiplin, dan ketekunan yang bermanfaat untuk masa depan anak.

3. Selama pemberian materi anak-anak sangat antusias, dan dalam sesi tanyajawab anak-anak antusias untuk bertanya walaupun sedikit malu-malu. Pertanyaan yang ditanyakan di jawab dengan bahasa yang mudah di pahami anak-anak agar mereka dapat menggali informasi dan pengetahuan lebih banyak lagi.

Setelah melaksanakan Program Kreativitas Mahasiswa (PKM) dengan 
tema Menumbuhkan Jiwa Kepemimpinan pada Anak Melalui Edukasi Digital penulis memberikan saran:

1. Agar Anak-anak bias belajar dan memahami apa yang telah diajarkan selama PKM maupun selama mereka belajar di sekolah tentang kepemimpinan.

2. Lebih mengembangkan potensi jiwa kepemimpinan mereka seperti menjadi ketua kelas atau memimpin kelompok belajar agar nantinya dapat berguna dalam dunia khusunya di era modern ini.

\section{DAFTAR PUSTAKA}

Azwar, Azrul, 1996. "Menjaga Mutu Pelayanan Kesehatan”. Jakarta: Pustaka Sinar Harapan.

Bryson, John M. 1988. "Strategic Palnning for Public and Non profit Organizations". Jossey-Bass Inc, San Fransisco, 1

Herlambang, Susatyo. 2013. "Pengantar Manajemen" Yogyakarta: GosyenPublising.

Kotler, Philip. 1983. "Strategy Marketing for Nonprofit Organizations Casses and Reading 3 ed", Prentice-Hall International Inc, Englewood, Cliffs, NY.

Mulyadi. 1998. "Total Quality Management". Yogyakarta: Universitas Gajah Mada.

Scholtes, Peter T 1988. "The Team Handbook How ToUse Teams to Improve Quality". Joiner
Assosiates Inc, Madison.

$$
\underset{\text { Pttps://id.wikipedia.org/wiki/Anak }}{\text { Pengertian }}
$$

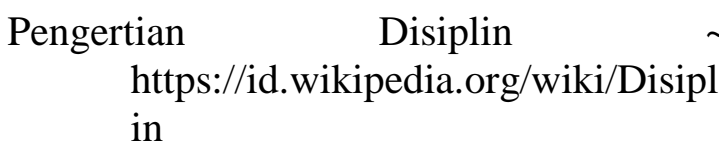
in

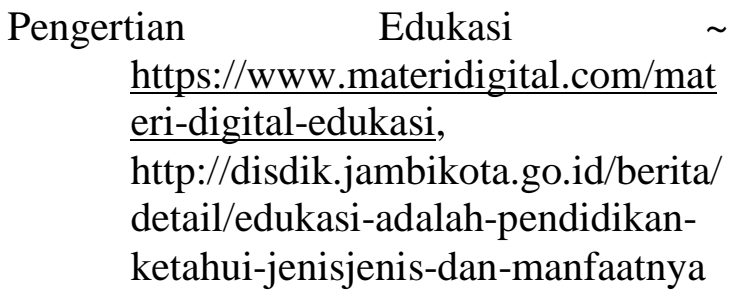

